\title{
Use of an in Vitro System to Study the Effects of Lead on Astrocyte- Endothelial Cell Interactions: A Model for Studying Toxic Injury to the Blood-Brain Barrier
}

\author{
AnN Marie Gebhart and Gary W. Goldstein \\ University of Michigan, Section of Pediatric Neurology, R6060 Kresge II, Box 0570 , \\ Ann Arbor, Michigan 48109-0570
}

Received August 25, 1987; accepted February 10, 1988

\begin{abstract}
Use of an in Vitro System to Study the Effects of Lead on Astrocyte-Endothelial Cell Interactions: A Model for Studying Toxic Injury to the Blood-Brain Barrier. GEBHART, A. M., AND Goldstein, G. W. (1988). Toxicol. Appl. Pharmacol. 94, 191-206. We investigated the effect of inorganic lead on the interaction of immature rat astrocytes and bovine adrenal endothelial cells. The two cell types were cultured alone and in coculture in the presence or absence of lead acetate for up to 1 week. A battery of cell specific markers was used for cell identification. Newborn Sprague-Dawley rat brain astrocytes were more sensitive than bovine adrenal endothelial cells to the cytotoxic effects of 10-50 $\mu \mathrm{M}$ lead acetate, as demonstrated by a decrease in cell number and by the presence of intracellular vacuoles and detached cells. The number of astrocytes decreased to $50 \%$ of control after 4 days in culture at a concentration of $10 \mu \mathrm{M}$ lead. In contrast, a mitogenic effect of lead was observed on the endothelial cells at this concentration, with an increase in cell number to $110 \%$ of control. In coculture, the two cell types demonstrated a distinctive cellular organization and the astrocytes were less sensitive to the cytotoxic effects of lead than when they were cultured alone. A lead-enhanced induction of a neural capillary enzyme activity, $\gamma$-GTP, was detected histochemically in the coculture system. These results are consistent with a maturing or differentiating effect of the endothelial cells on the astrocytes, making them less susceptible to lead and mature enough to induce $\gamma$-GTP activity in the endothelial cells. 1988 Academic Press, Inc.
\end{abstract}

An acute encephalopathy similar to that found in lead-poisoned children can be experimentally produced in vivo by lead administration to rats during the suckling period (Clasen et al., 1974; Lefaucannier et al., 1980; Pentschew and Garro, 1966; Goldstein et al., 1974). In each case, the entire brain becomes swollen and edematous and a severe hemorrhage reaction, including necrosis, occurs in the ccrebellum where capillary permeability is altered. In recent years, the emphasis has shifted to chronic, low-level lead exposure and the special sensitivity of children (Silbergeld, 1985). Lower lead levels are now associated with a whole range of neurological func- tional impairments, including learning and behavior problems.

Brain capillary endothelial cells (BCECs), which are responsible for formation of the blood-brain barrier (BBB), are a major site of lead accumulation in autoradiographic studies done in developing rats (Thomas et al., 1973). Capillary-enriched microvascular preparations, a good source of BCECs, have been isolated from rats poisoned with lead in vivo and found to be enriched in lead compared to whole brain (Toews et al., 1978). Capillary preparations also provide an opportunity to study structural and enzymatic properties of the BBB at a biochemical level. 
For instance, isolated brain microvessels were useful in developing an association between lead toxicity and alterations in calcium homeostasis (Goldstein et al., 1977) and in establishing the intracellular distribution of lead-calcium complexes (Silbergeld et al., 1980). However, studies with capillary preparations are limited by exposure times of no more than several hours and by the presence of more than one cell type.

The focus of this work is endothelial cell (EC)-glial cell interactions, which may be vulnerable at low levels of lead exposure. Two features that make the microvessels of the brain distinctive from systemic microvessels are the continuous tight junctions of the BCECs, in which the outer leaflet of two adjoining cells merge, and the astrocytic foot processes, which nearly surround the anti-luminal side of the capillary (Wolff, 1963; Reese and Karnovsky, 1967; Brightman, 1977; Brightman and Reese, 1969). The tight junctions of the BCECs have long been credited with providing the anatomical basis of the BBB, although it has been suggested that the astrocytic end feet are responsible for inducing and maintaining at least some of the barrier functions of the BCECs (Davson and Oldendorf, 1967; DeBault and Cancilla, 1980 c). Circumstantial evidence for this includes the absence of both a glial sheath and a barrier in certain regions of the brain (choroid plexus, pineal gland, pituitary) and in cranial neoplasms; and the coincidental development of the glial sheath and barrier function in the rat and chicken (Hirano et al., 1974; Bar and Wolff, 1972; Delorme et al., 1968). One long term goal of this laboratory is to determine in what way lead and other toxicants affect the induction by astrocytes of BBB properties in ECs.

An in vitro model of the $\mathrm{BBB}$ is being developed in this laboratory by growing small vessel bovine adrenal endothelial cells (BAECs) and rat brain astrocytes in coculture to study induction of BCEC properties in a nonneural EC line. The cultured BAECs should express more specialized properties of BCECs only when in culture with the astrocytes if induction of these properties results from BAEC-astrocyte interactions. The morphology of these two cell types in culture is density and substratum dependent. A battery of immunological and cytochemical markers used to identify the cell types present in our cultures is described. The subjects of this report include a comparison of the toxic effects of lead on BAECs and on astrocytes in culture, and the effects of lead on the organization and interaction of these cells in coculture.

\section{METHODS}

Cell culture. The endothelial cells used in these studies were from a line of bovine adrenal microvessel endothelium (BAEC) and were a kind gift of Dr. M. Furie (Pathology Dept, State University of New York at Stony Brook). The cells were maintained in MEM $\alpha$ medium (GIBCO Laboratories) supplemented with $15 \%$ defined bovine calf serum (Hyclone) and $1 \%$ penicillin-streptomycin $(100 \mathrm{U} / \mathrm{ml} ; 100 \mu \mathrm{g} / \mathrm{ml})$. The cells were grown on plastic and incubated at $37^{\circ} \mathrm{C}$ in a humidified atmosphere containing $5 \% \mathrm{CO}_{2}$. All cells used in these studies were between passages 13 and 17 and identified by their typical morphology and by the cell specific markers described below. Astrocytes were isolated from newborn Sprague-Dawley rat brain as described by Frangakis and Kimelberg (1984). Cells were maintained on plastic in Dulbecco's MEM supplemented with $10 \%$ bovine calf serum and $1 \%$ penicillin-streptomycin at $37^{\circ} \mathrm{C}$ in $5 \% \mathrm{CO}_{2}$ humidified atmosphere. For these studies, astrocytes that were grown in coculture or as astrocyte controls for coculture were grown in the BAEC medium described. BAECs were plated 1 day earlier than were the astrocytes, unless otherwise indicated. Both cell types were seeded in the range of $10,000-20,000$ cells $/ \mathrm{cm}^{2}$ and cultures were fed by replacing one-half of the old medium with an equivalent volume of fresh medium.

Cell specific markers. The presence of the cell specific markers factor VIII/von Willebrand factor (vWF) and angiotensin-converting enzyme were used to identify endothelial cells and glial fibrillary acidic protein (GFAP) was used to identify astrocytes. Indirect fluorescent antibody staining was employed using rabbit anti-human factor VIII/vWF (Behring Diagnostics), mouse anti-angiotensin-converting enzyme, a generous gift of Dr. R. Auerbach (Department of Zoology, University of Wisconsin), or rabbit anti-cow GFAP (Accurate Chemical 
Corp.) at 1:10 dilution. The secondary antibody was fluorescein conjugated goat anti-rabbit IgG (Cappel) at 1:20 dilution or goat anti-mouse IgM (Cappel) at 1:10 dilution. Negative controls were run using normal goat serum in place of the primary antibody. Endothelial cells were also specifically labeled based on their increased uptake of acctylated low density lipoprotein (Voyta et al., 1984) labeled with the fluorescent probe 1, 1'-dioctadecyl1-3,3,3',3'-tetramethyl-indo-carbocyanine percholate (Biomedical Technologies, Inc., Stoughton, MA). For all markers, fluorescent labeling was graded on a Leitz fluorescence microscope according to the following scheme:

$$
\begin{array}{ll}
0 & \text { no cells labeled } \\
+/ 0 & \text { rare cell labeled (1-4\% of cells) } \\
+ & \text { occasional cell labeled (5-10\% of cells) } \\
+/++ & \text { few cells labeled (11-30\% of cells) } \\
++ & \text { half of cells labeled }(31-70 \% \text { of cells) } \\
++/+++ & \text { many of cells labeled (71-90\% of cells) } \\
+++ & \text { most of cells labeled }(91-99 \% \text { of cells) } \\
++++ & \text { all of cells labeled }
\end{array}
$$

$\gamma$-Glutamyl transpeptidase ( $\gamma$-GTP) activity $\gamma$-GTP activity was analyzed histochemically on acetone:ethanol fixed preparations of cultured cells according to the method of DeBault and Cancilla (1980a).

Lead solutions. A stock solution of $5 \mathrm{~mm}$ lead acetate in sterile distilled water was diluted to the desired final concentrations in the culture medium. After attaching, cells were grown continuously in the lead-containing medium.

Cytotoxicity. Cell cultures were viewed with a light microscope and graded for cytotoxicity according to the following scheme:

$0 \quad$ Cells appear normal; no cytotoxicity visible. +10 Occasional cell vacuolated.

$+\quad$ Few cells vacuolated, rounded or detached.

+ Several cells vacuolated, rounded or detached.

++ Many cells appear washed-out, with large vacuoles; many detached cells.

++++ Most cells appear washed-out, with large vacuoles; very few attached cells.

Cell counting and statistics. Cells grown in 6- or 12 well culture dishes were rinsed, trypsinized, dispersed with the addition of serum-free medium and repeated pipetting, and counted in a Coulter counter. Duplicate wells were counted in each experiment. Significance levels were calculated by the two-tailed Student's $t$ test for independent samples.

\section{RESULTS}

\section{Cell Identification}

We chose a non-brain small vessel $\mathrm{EC}$ line to develop our in vitro model of the BBB. The
TABLE 1

Cell identification: Presence of Cell Specific MARKERS AS DETECTED By FLUORESCENT LABELING

BAEC Astrocytes Coculture

\begin{tabular}{lccc}
\hline Anti-factor VIII/vWF & ++++ & 0 & ++ \\
Anti-GFAP & 0 & +++ & ++ \\
Anti-ACE & ++++ & $+/ 0$ & ++ \\
Uptake of Dil-Ac-LD & ++++ & + & ++ \\
\hline
\end{tabular}

Note. Grading for number of cells fluorescently labeled: $0=$ none; $+/ 0=$ rare; $+=$ occasional; $++=$ half; $+++=\operatorname{most} ;++++=$ all.

cultured BAECs should express more specialized properties of BCECs only when in culture with the astrocytes if induction of these properties results from BAEC-astrocyte interactions. Cell identification is critical in these experiments and the results obtained with cell specific markers are summarized in Table 1.

Factor VIII/vWF is the most widely used marker for EC identification and is present in brain capillaries in vivo (DeBault and Cancilla, 1980c). Except for megakaryocytes and platelets it is found exclusively in ECs where it is stored in cell specific organelles. The bovine adrenal EC line used in these studies is reported to be $100 \%$ positive when stained with anti-bovine factor VIII/vWF (Furie et al., 1984). We found a weaker reaction, but with a similar high incidence of positive cells, with the commercially available rabbit antihuman factor VIII/vWF. Approximately one-half of the cells in coculture were positive with the anti-human factor VIII/vWF (Fig. 1A).

GFAP is a major component of glial filaments and is astrocyte specific in indirect immunofluorescent and immunoperoxidase studies in vivo and in vitro (Antanitus et al., 1975; Ludwin et al., 1976). Our astrocyte cultures were consistently $90+\%$ positive for GFAP in primary, P1, and P2 cultures. Cocultures of BAECs and astrocytes were GFAP positive in some areas, which in early cocul- 

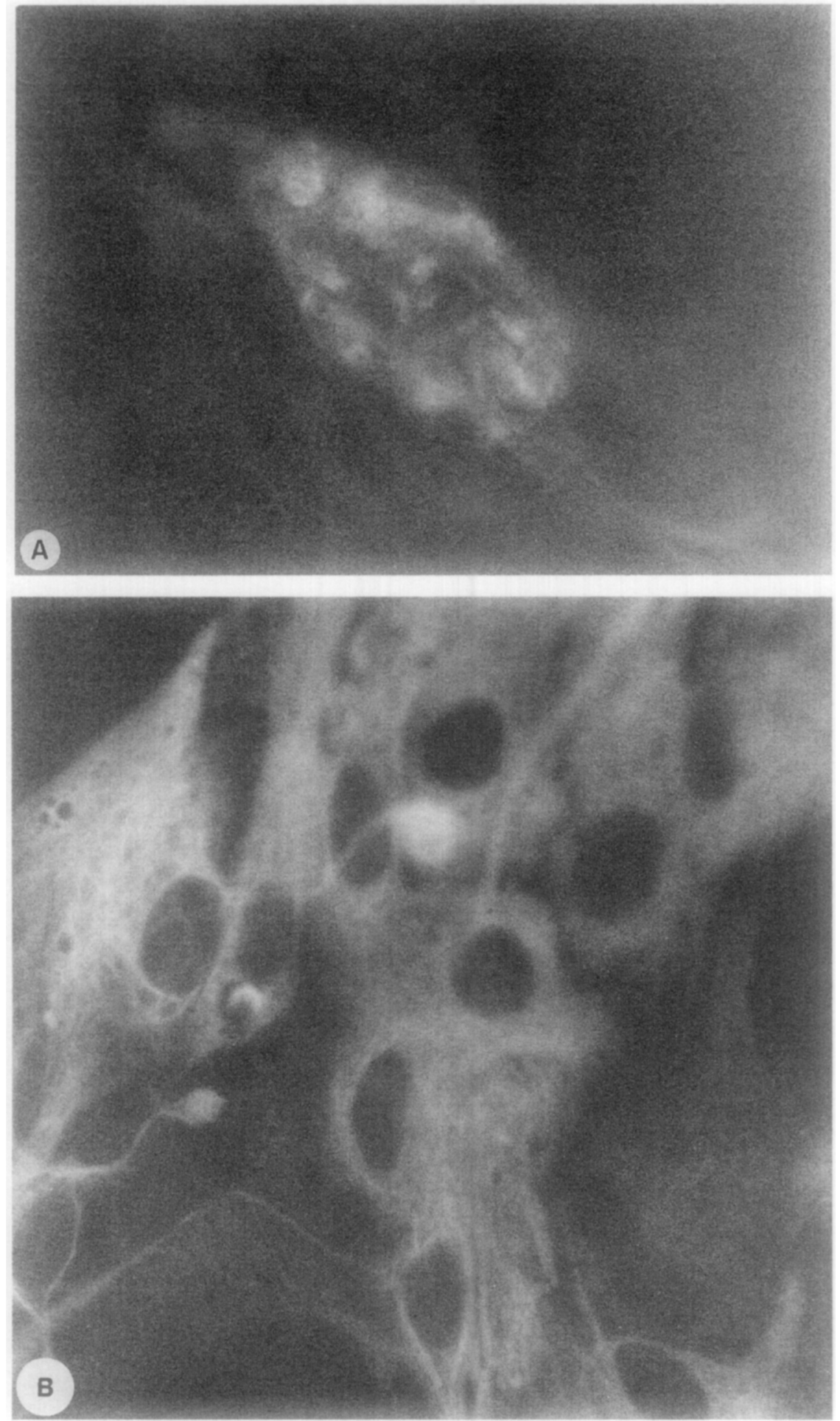

FIG. 1. Light micrographs of BAECs and rat astrocytes in coculture fluorescently labeled with (A) Factor VIII/vWF and (B) GFAP. 
tures, were distinct from those areas positive for factor VIII/vWF (Fig. 1B).

Angiotensin-converting enzyme is a surface protein that serves as a useful marker for ECs in capillaries, veins, and arteries (Auerbach et al., 1982). Although angiotensin-converting enzyme activity is present in pericytes and smooth muscle cells, these cells have much lower activity than capillary ECs (Bowman et al., 1981; Hial et al., 1979). The BAECs demonstrated positive immunofluorescent staining of increasing intensity at increasing antibody concentrations. Astrocytes were negative except for a cluster of positively stained cells observed once, which were presumably endothelial in origin as a pericyte culture was negative for this antibody (data not shown). Cocultures showed varying degrees of positive staining, most frequently associated with the areas of distinct cellular organization.

Acetylated low density lipoprotein uptake occurs by a receptor mediated process at elevated rates in macrophages and ECs relative to smooth muscle cells and pericytes (Voyta et al., 1984). The attached fluorescent probe is lipophilic and remains within the cells following degradation of the lipoprotein. This marker consistently labeled $100 \%$ of the cells in our BAEC line and approximately $5 \%$ of the cells in our glial cultures. The cocultures also had many fluorescent cells, particularly those associated with the tubular structures.

The labeling of cells by these markers was also examined in the presence of $10 \mu \mathrm{M}$ lead acetate. No effect of lead was observed on degree of fluorescence or on number of positively labeled cells.

\section{Cytotoxicity of Lead}

The BAECs were seeded at different densities, allowed to attach overnight, and then maintained in lead-containing medium for up to 10 days. A cytotoxic effect was observed on these cells only at the highest dose of lead, a concentration close to its limits of solubility (Figs. 2A-2D). Astrocytes were seeded, allowed to attach for several hours, and then maintained in the same lead-containing medium (MEM- $\alpha$ ) used for the BAECs. Over the same dose range, the astrocytes were much more susceptible to the cytotoxic effects of lead than were the BAECs (Figs. 2E-2H). Even at the lowest dose, fewer attached cells and more rounded and floating cells were observed in the astrocyte culture. The relative cytotoxicity of lead on the two cell types is summarized in Table 2. Preliminary studies indicated that the morphology and survival of the astrocytes were not affected by growing them in MEM- $\alpha$, the endothelial medium. In the cocultures, the astrocytes were added to the same wells in which the BAECs had been seeded on the previous day. After 1 week, the cytotoxic effect of lead on the cocultures was intermediate between that on either the BAECs or the astrocytes alone in culture.

The difference in susceptibility to lead observed morphologically between BAECs and astrocytes was also evident in the lead-induced effect on cell number. In every case examined, regardless of seeding density, dose, or time of exposure to lead, cell number, expressed as a percentage of control, was decreased for the astrocytes. The effect of lead on cell number of BAECs was somewhat variable from experiment to experiment depending on seeding density and time of exposure to lead. In some cases, the number of lead-treated BAECs was below that of control, but this was only consistently found at the highest dose level tested $(500 \mu \mathrm{M})$. At all other tested levels of lead exposure, BAEC number was often at or above control values, suggesting a mitogenic effect of lead on these cells under the proper conditions. Figure 3 summarizes the difference between the effect of lead on cell number of BAECs and of astrocytes at concentrations of 10,30 , and $50 \mu \mathrm{M}$ after 4 and 7 days in culture. The difference is significant at each time point and dose level. The number of each cell type, when ex- 
pressed as a percentage of control, decreased from 4 days to 7 days in culture, but the actual number of cells in control wells doubled or tripled in every case during this time. This difference between BAECs and astrocytes is also seen in Fig. 4, a graph of the effect of lead on cell number from a single experiment. The mitogenic effect of lead on BAECs most often peaked at a concentration of $10 \mu \mathrm{M}$, as it did in this experiment. In contrast, the number of astrocytes decreascd to $50 \%$ of control at a concentration of $10 \mu \mathrm{M}$ lead and remained near this level at all higher lead concentrations.

\section{Endothelial Cell and Astrocyte Interactions in Coculture}

When grown together for 2-3 days in the same well, BAECs tended to organize into tight islands of cells with more loosely associated groups of astrocytes in between them. This pattern of growth was observed whether BAECs or astrocytes were plated first into the well and it occurred over a range of BAEC: astrocyte plating density ratios, in which one cell type varied from one-third to three times the number of the second cell type. If the number of one cell type was much greater than the second cell type, the cellular organization would be lost and the predominant cell would overwhelm the coculture. After 23 days in coculture, endothelial and astrocytic areas of growth were identified as such both morphologically and with markers (Fig. 1). The early coculture was relatively resistant to the cytotoxic effects of lead up to a concentration of $50 \mu \mathrm{M}$, as were the BAECs when cultured alone, but unlike the astrocytes, which showed marked cytotoxicity at 10-50 $\mu \mathrm{M}$ lead when cultured alone (Table 2).
By 1 week in coculture, the cellular organization became more complex and individual cell types more difficult to identify. Grossly visible structures were observed either in the form of large nodules of cells that were several ccll laycrs dcep (Fig. 5B) or in the form of long tubular structures. These more complex forms of cellular organization were observed in control wells but were found with the greatest frequency in cultures exposed to low levels of lead $(1-10 \mu \mathrm{M})$. Some cclls within these structures were positively labeled with each of the cell specific markers used, and it was not possible to predict cell type morphologically. A very low level of cytotoxicity was observed at this time up through $30 \mu \mathrm{M}$ lead. The cellular organization was lost at 50 and $500 \mu \mathrm{M}$ lead as cytotoxicity became more evident (Table 2).

$\gamma$-GTP has been useful as a marker of BCECs (Orlowski et al., 1974; DeBault and Cancilla, 1980a) with a large increase in $\gamma$ GTP activity occurring in brain capillary preparations of 10- to 21-day-old rats (Sessa and Perez, 1975; Betz and Goldstein, 1981). The BAECs used in these studies were consistently negative for $\gamma$-GTP activity by the cytochemical method described, as would be predicted for a systemic microvascular EC line. In both control and lead-treated cocultures of BAECs and astrocytes, however, the areas of marked cellular organization (nodules, tubules) were $\gamma$-GTP positive (Fig. 5C). These areas appeared to be a mixture of endothelial and astrocytic cells by marker assays.

\section{DISCUSSION}

We present here a novel coculture system to explore the effect of lead upon cellular interactions important to the formation and

FIG. 2. Light micrographs of $0 \mu \mathrm{M}$ and lead-exposed cells after 5-6 days in culture. BAECs: (A) $0 \mu \mathrm{M}$, (B) $10 \mu \mathrm{M}$, (C) $50 \mu \mathrm{M}$, and (D) $500 \mu \mathrm{M}$ lead. Astrocytes: (E) $0 \mu \mathrm{M}$, (F) $10 \mu \mathrm{M}$, (G) $50 \mu \mathrm{M}$, and (H) $500 \mu \mathrm{M}$ lead. 

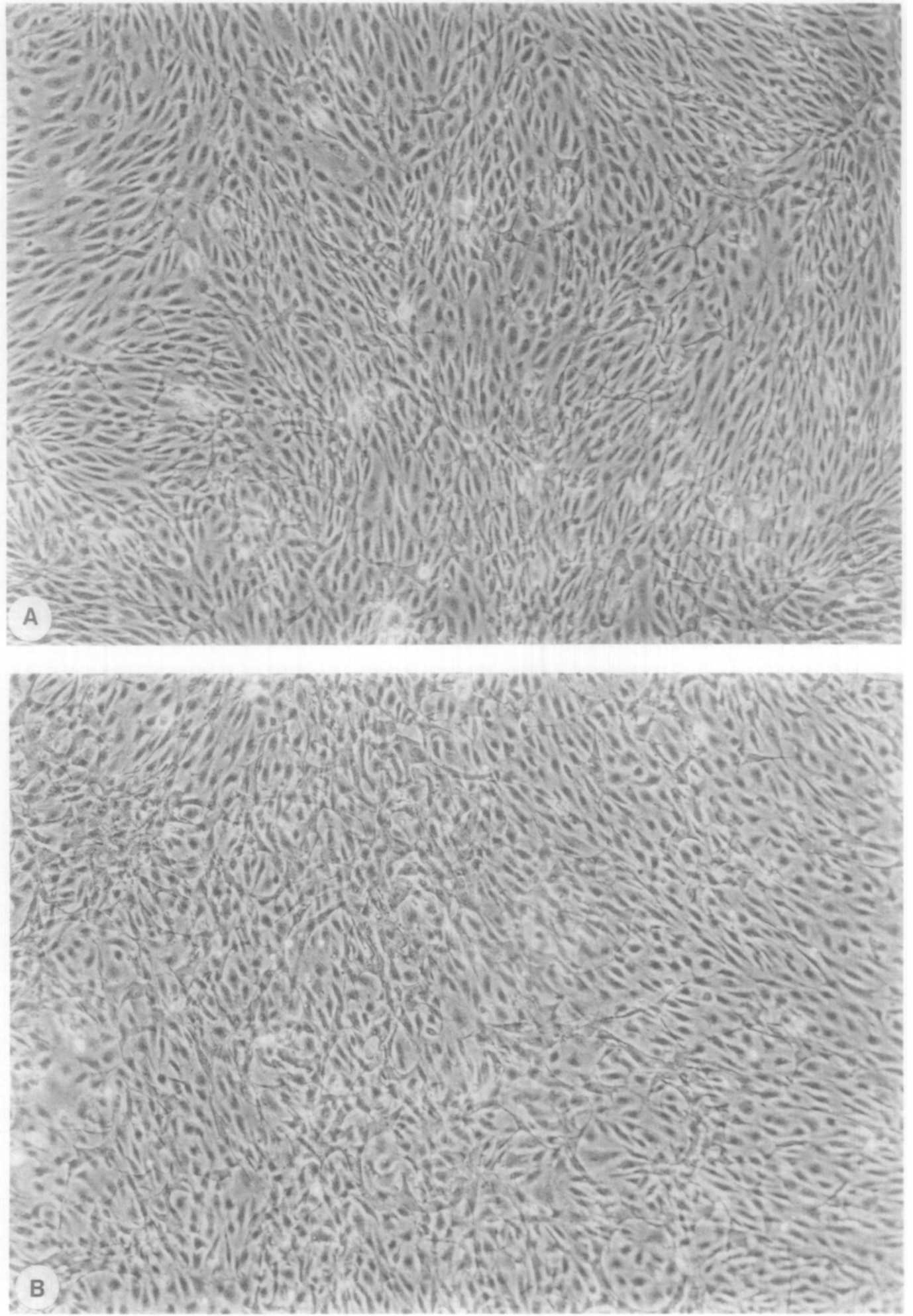

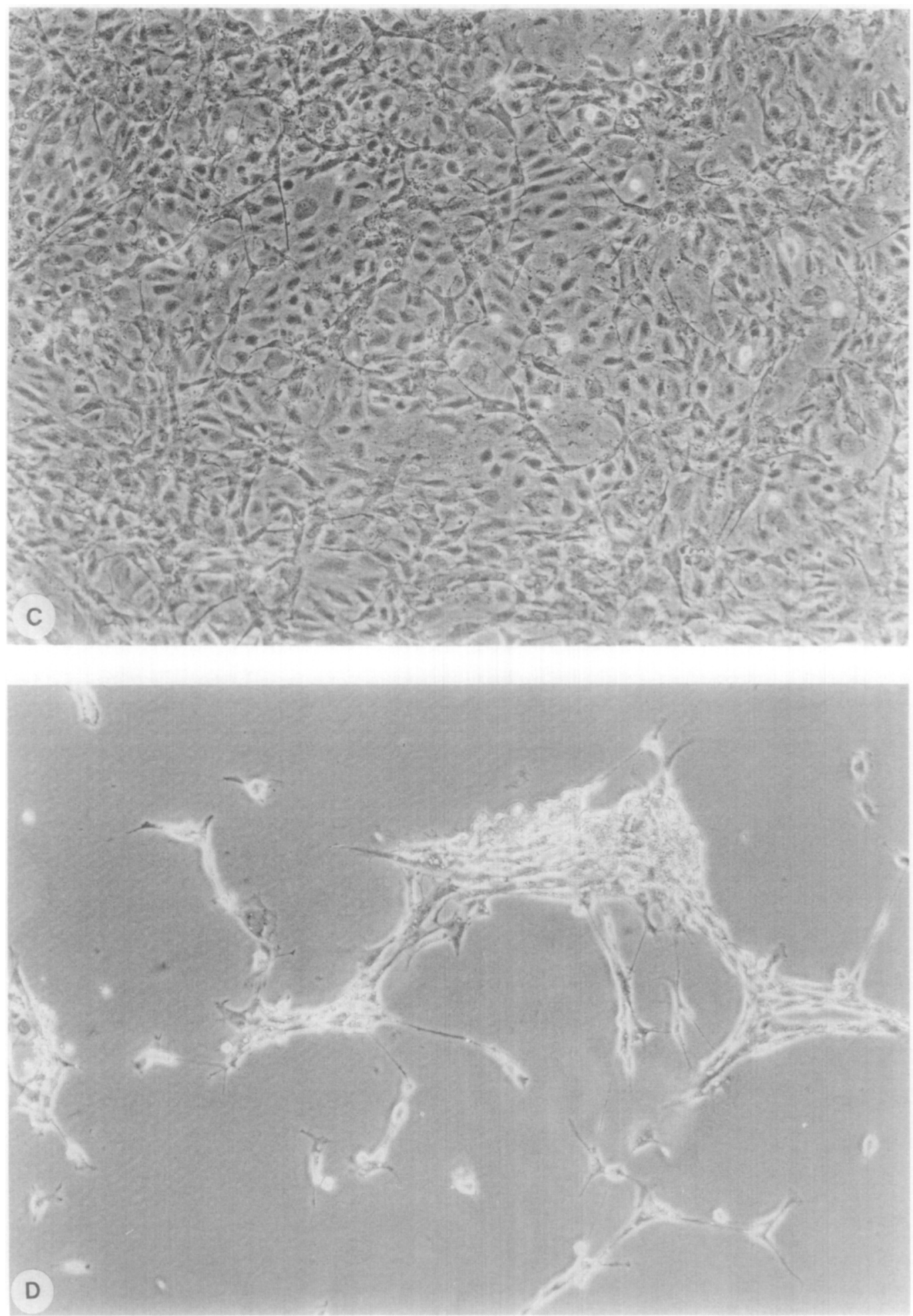

Fig. 2-Continued 

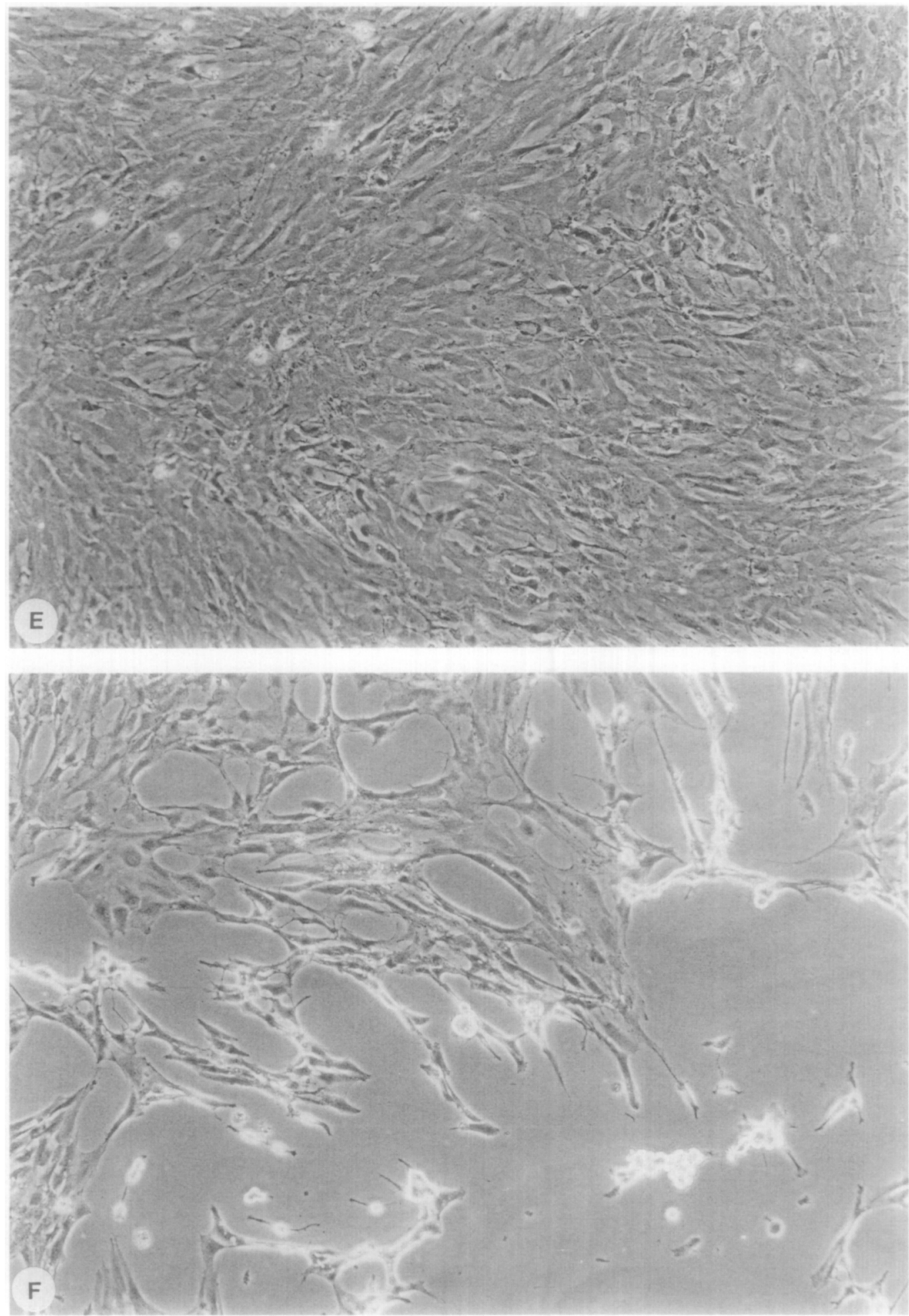

Fig. 2-Continued 

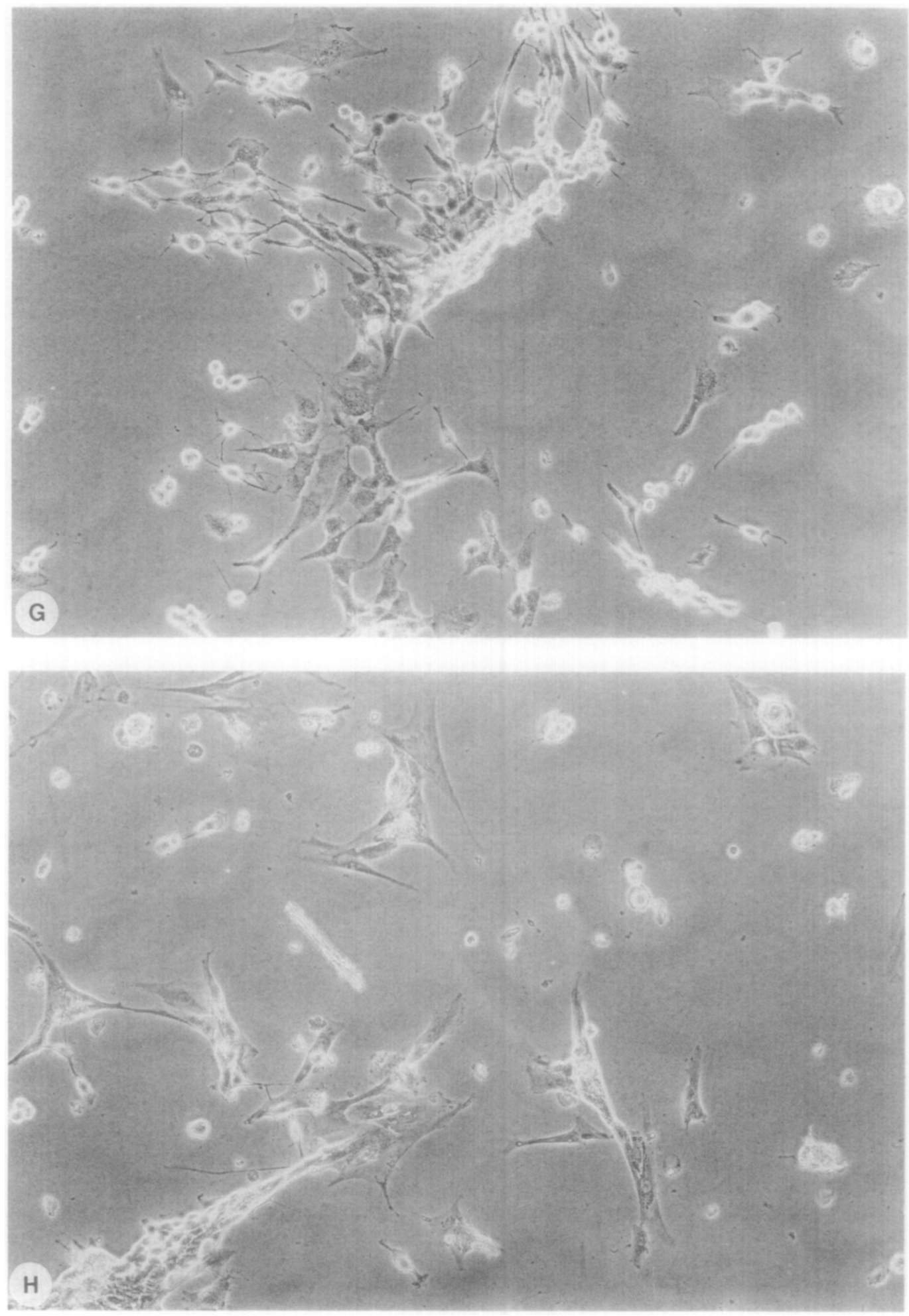

FIG. 2-Continued. 
TABLE 2

RELATIVE CYTOTOXICITY OF LEAD AS A FUNCTION OF CONCENTRATION AND TIME OF EXPOSURE IN VITRO

\begin{tabular}{|c|c|c|c|c|c|c|}
\hline \multirow{2}{*}{$\begin{array}{c}\text { Pb acetate } \\
\text { concentration }(\mu \mathrm{M})\end{array}$} & \multicolumn{2}{|c|}{ BAEC } & \multicolumn{2}{|c|}{ Astrocytes } & \multicolumn{2}{|c|}{ Coculture } \\
\hline & 2 days & 7 days & 2 days & 7 days & 2 days & 7 days \\
\hline 5 & 0 & 0 & $+/ 0$ & $+/ 0$ & 0 & $+/ 0$ \\
\hline 10 & 0 & 0 & + & ++ & 0 & $+/ 0$ \\
\hline 30 & 0 & 0 & ++ & +++ & 0 & $+/ 0$ \\
\hline 50 & 0 & $+/ 0$ & +++ & +++ & 0 & + \\
\hline 500 & +++ & +++ & $+++t$ & $t+t+$ & $t+t$ & +++ \\
\hline
\end{tabular}

Note. Grading for cytotoxicity, defined as the presence of intracellular vacuoles, rounded or detached cells, or a washed-out, abnormal appearance: $0=$ none; $+/ 0=$ occasional vacuole; $t=$ few vacuolated or detached cells; ++ $=$ several vacuolated or detached cells; $+++=$ many cells vacuolated and washed-out or detached; $++++=$ most cells vacuolated and washed-out or detached.

functioning of the BBB. This in vitro model utilizes astrocytes derived from rat brain, the standard source for the isolation and culture of this cell type (Frangakis and Kimelberg, 1984), and bovine adrenal microvascular ECs, a well established systemic EC line (Furie et al., 1984; Lombardi et al., 1986). The precedent of using different species to study induction of BBB properties has been established by others. The activity of $\gamma$-GTP, demonstrated histochemically to be present in vivo in mouse BCECs, is lost with time in cul-

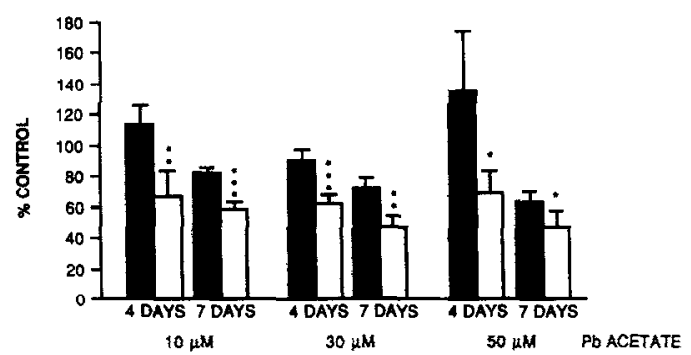

FIG. 3. Effect of lead concentration and time of exposure on cell growth. BAECs (shaded bars) and rat brain astrocytes (open bars) were allowed to attach and then exposed to lead-containing medium for the times indicated. Each value is the mean \pm SD of four experiments. Significance levels were calculated by Student's $t$ test for independent samples. Number of astrocytes were significantly different from number of BAECs at each dose level and time point: ${ }^{* * *} p<0.001 ;{ }^{* *} p<0.01 ;{ }^{*} p<0.05$. ture, but can be induced by coculture with rat C6 glioma cells (DeBault and Cancilla, $1980 \mathrm{~b}$ ). This induction of $\gamma$-GTP activity also occurs if the glioma cells arc used only to condition media (Maxwell et al., 1987). The importance of astrocyte induction of properties necessary for BCECs to form the BBB is also supported by cross-species transplantation studies. Janzer and Raff (1987) purified astrocytes of neonatal Sprague-Dawley rats, cultured them on small Millipore filters, and then placed them cell side down onto the chorioallantoic membrane of 5-day-old chick

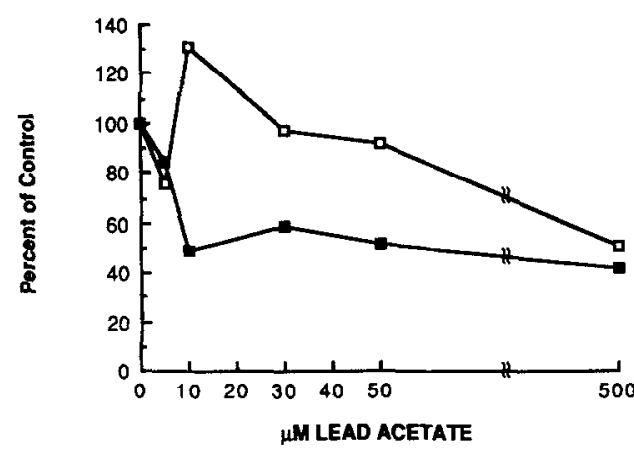

FIG. 4. Effect of lead concentration on cell growth. Data are from a single experiment that is typical of the divergent response of BAECs (open squares) and astrocytes (closed squares) to lead after 4 days of exposure in culture. The number of $0 \mu \mathrm{M}$ cells in each case was 77,700 BAECs and 93,000 astrocytes. 

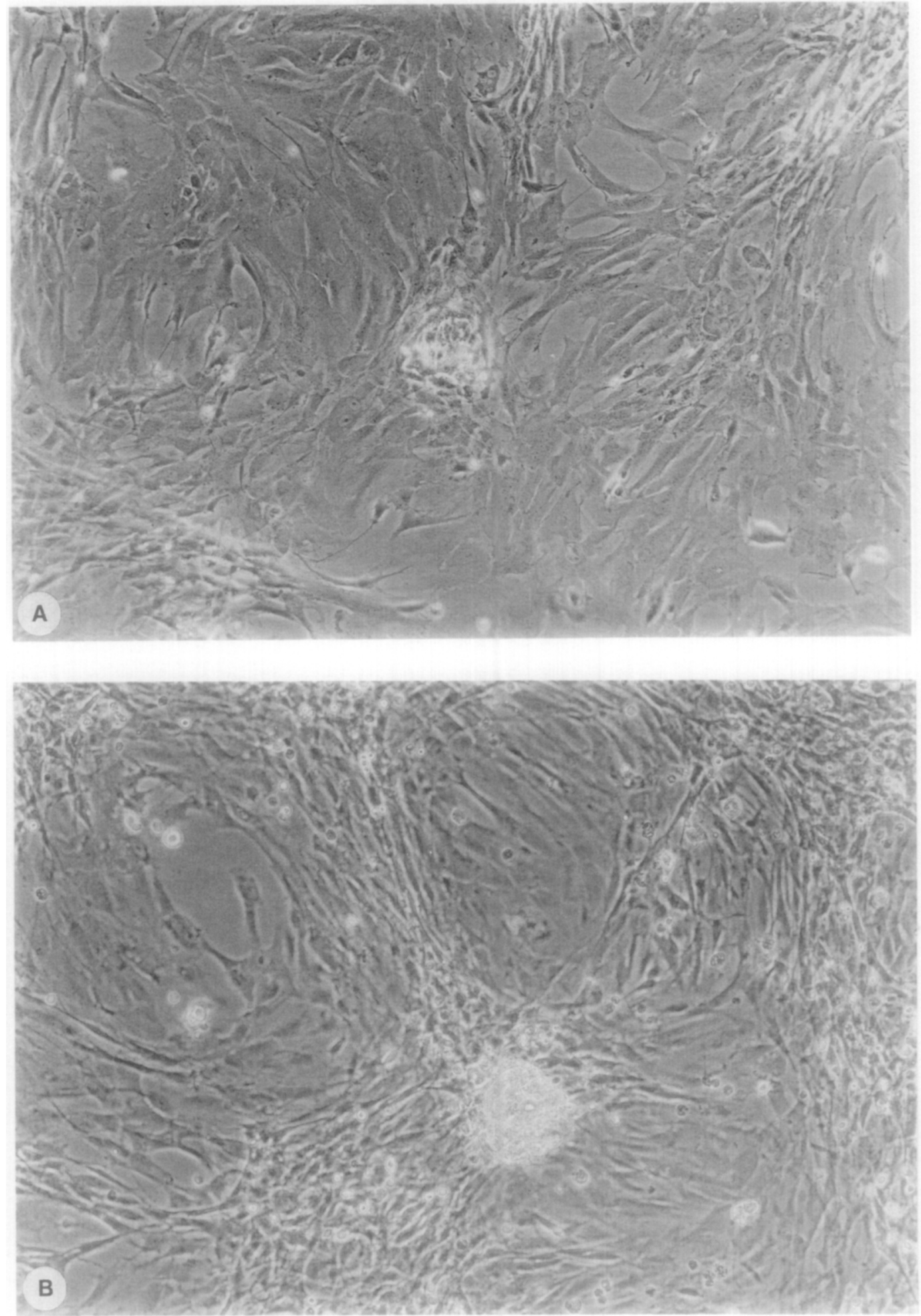

FIG. 5. Light micrographs of cocultures of BAECs and astrocytes showing the progression of cellular organization from (A) cellular islands, 2-3 cell layers deep, to (B) large nodules of cells, 7-8 cell layers deep. These nodules of cells reacted positively for $\gamma$-GTP activity by the cytochemical method described (C). 


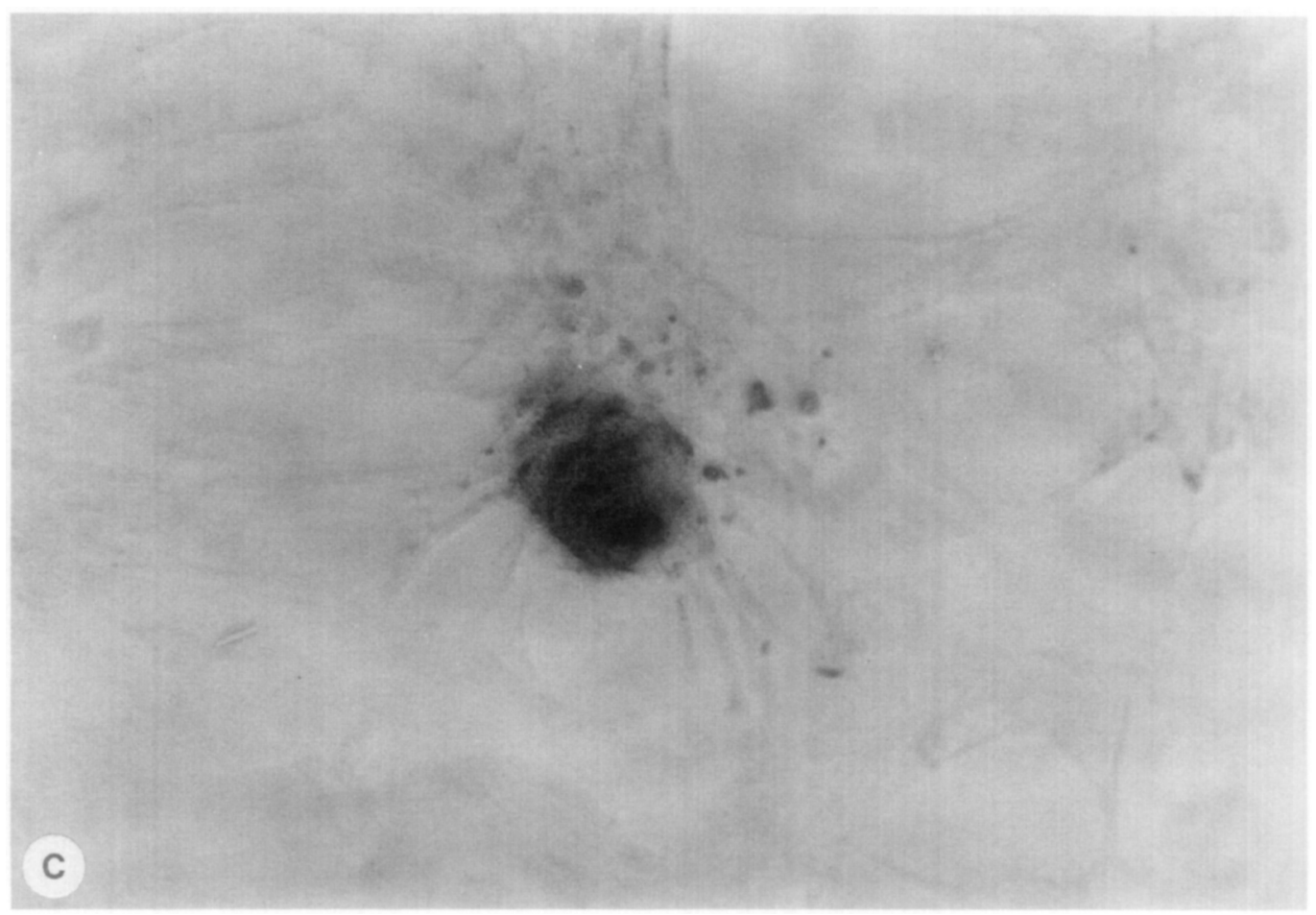

FIG. 5-Continued.

embryos. The vessels that formed within the astrocyte aggregates were nonleaky, providing evidence that the rat astrocytes induced nonneural chick ECs to form a tight barrier. The use of different species enabled them to prove that the ECs within the astrocyte aggregates were of chick origin and not contaminating rat neural ECs. Similarly, when Stewart and Wiley (1981) transplanted avascular brain fragments from quail embryos into the coelomic cavity of chick embryos, the quail grafts were vascularized by nonneural chick ECs that formed structural, functional, and histochemical features of the BBB. Fragments of avascular quail coelomic tissue, grafted into embryonic chick brain, were vascularized by leaky vessels. Again, two species were used as sources of different cells to study the importance of the neural environment in inducing BBB characteristics in ECs. In vitro models of this interaction should help to de- termine more specifically the mediators of astrocyte induction.

We used neonatal rat astrocytes in direct coculture with a nonneural bovine EC line to study induction of $\mathrm{BBB}$ properties in an in vitro model system. A battery of cell specific markers was used to identify the two cell types in this system. After a week in coculture, the cells became highly organized into structures that appeared to be made up of both cell types intimately associated, paralleling the in vivo situation. These structures became $\gamma$-GTP positive histochemically (Fig. $5 \mathrm{C}$ ), suggesting that the rat astrocytes induced a specialized property of BCECs in a nonneural EC line.

We examined the effects of lead on our coculture system, as well as on the two cell types individually, since $\mathrm{EC}$-astrocyte interactions may be vulnerable to toxic injury. Our results indicate that immature rat astrocytes are 
more sensitive to the cytotoxic effects of lead than are the BAECs. Our reasons for using more than one species have been discussed and we are not attempting to make any species-related assumptions about lead toxicity. However, results of a pilot study indicated that the survival and growth of rat BCECs were not affected by the presence of $100 \mu \mathrm{M}$ lead acetate for up to 1 week (Bowman, personal communication). This suggests that the greater susceptibility of astrocytes to the toxic effects of lead is not the result of species differences. Nevertheless, this issue is not resolved since Maxwell et al. (1986) report a decrease in glucose analog uptake, cell number, and thymidine incorporation in cultured mouse BCECs exposed to lead acetate.

Our studies demonstrated a mitogenic effect of lead on monocultures of BAECs (Fig. 4). Lead also has a proliferative effect on liver and kidney cells. Lead acetate stimulates RNA, DNA, and protein synthesis in mouse kidney cells, and increases cell proliferation in rat kidney cells (Choie and Richter, 1972; Choie and Richter, 1974a,b). A single dose of lead nitrate increased total protein, DNA content, and number of cells entering mitosis in both parenchymal and nonparenchymal rat liver cells with no detectable liver necrosis (Columbano et al., 1983). The mechanism by which lead enhances cell growth has not yet been determined.

In contrast to a growth promoting effect on BAECs, we found cytotopathic changes and a decrease in cell number in our lead-treated astrocytes (Table 2; Fig. 4). A lead concentration-dependent increase in number of detached astrocytes was also reported by $\mathrm{Ngu}$ yen et al. (1982). These authors demonstrated a cytotoxic effect of lead in SpragueDawley rat astrocytes by scanning and transmission electron microscopy. Vacuoles, areas of clearing, and surface changes, including an increase in surface blebs and a decrease in microvilli and membrane folds, were detected in astrocytes exposed to lead acetate. Tiffany $e t$ al. (1987) report a decrease in cell number when astrocytes from immature Wistar rats were cultured in the presence of $1 \mu \mathrm{M}$ lead acetate. Interestingly, mature Sprague-Dawley rat astrocytes were resistant to low concentrations of lead and had less intracellular lead than the immature astrocytes, especially at low doses. The authors conclude that astrocytes act as a lead sink and a direct target for cellular damage in lead toxicity. Their findings support the suggestion of Holtzman et al. (1984) that the development of resistance to lead encephalopathy in adult rats is associated with the sequestering of lead by mature astrocytes away from the mitochondria to nontoxic sites. At least three aspects of lead toxicity are mitochondria-related: heme synthesis, oxidative phosphorylation, and intracellular calcium metabolism. The mitochondria is therefore a critical subcellular target in lead neurotoxicity and the ability to protect this site is important for maturing astrocytes.

In this study, we demonstrated the induction of a neural capillary enzyme activity in the coculture of a nonneural EC line with astrocytes (Fig. 5C). Within this interacting system we found that astrocytes are more resistant to the cytotoxic effects of lead than when they are cultured alone. As discussed, the development of resistance to the toxic effects of lead in astrocytes has been linked with their maturation. One explanation for the increased resistance of astrocytes to lead in coculture with BAECs would be a maturation due to interactions between the two cell types. In fact, this coculture may serve as a model of cellular differentiation and of the importance of cell-cell interactions during development. The maturation of interacting cells in coculture would also be consistent with the induction of $\gamma$-GTP activity, which appears to be enhanced in the presence of lead. This suggests that, in vivo, lead may disturb the programmed growth and differentiation of the BBB and underlie some of the neural effects of exposure to low levels of lead. Our results emphasize the importance of cellular interactions in determining the re- 
action to a toxicant and suggest that pure monocultures may not best represent the response of a tissue.

\section{ACKNOWLEDGMENT}

This study was supported by NIEHS Grant ESO2380.

\section{REFERENCES}

antanitus, D. S., ChoI, B. H., AND Lapham, L. W. (1975). Immunofluorescence staining of astrocytes in vitro using antiserum to glial fibrillary acidic protein. Brain Res. 89, 363-367.

AUERBaCh, R. L., Alby, L., Grieves, J., JosePH, J., LiNDGEN, C., MORRISEY, L. W., SidKy, Y. A., TU, M., AND WATT, S. L. (1982). Monoclonal antibody against agiotensin-converting enzyme: Its use as a marker for murine, bovine, and human endothelial cells. Proc. Natl. Acad. Sci. USA 79, 7891-7895.

BAR, TH., AND WolfF, J. F. (1972). The formation of capillary basement membranes during internal vascularization of the rat's cerebral cortex. Z. Zellforsch. 133, 231-248.

Betz, A. L., AND GoldsteIN, G. W. (1981). Developmental changes in metabolism and transport properties of capillaries isolated from rat brain. J. Physiol. 312, 365-376.

Bowman, P. D., Betz, A. L., AR, D., Wolinsky, J. S., Penney, J. B., Shivers, R. R., AND Goldstein, G. W. (1981). Primary culture of capillary endothelium from rat brain. In Vitro. 17, 353-362.

BRIGHTMAN, M. W. (1977). Morphology of blood-brain interfaces. Exp. Eye Res. Suppl. 25, 1-25.

BRIGHTMAN, M. W., AND ReESE, T. S. (1969). Junctions between intimately apposed cell membranes in the vertebrate brain. J. Cell Biol. 40, 648-677.

CHOIE, D. D., AND RichteR, G. W. (1972). Cell proliferation in rat kidney induced by lead acetate and effects of uninephrectomy on the proliferation. Amer. J. Pathol. 66, 265-276.

ChOIE, D. D., AND RICHTER, G. W. (1974a). Cell proliferation in mouse kidney induced by lead. I. Synthesis of deoxyribonucleic acid. Lab. Invest. 30, 647-651.

ChoIE, D. D., AND Richter, G. W. (1974b). Cell proliferation in mouse kidney induced by lead. II. Synthesis of ribonucleic acid and protein. Lab. Invest. 30, 652656.

Clasen, R. A., Hartmann, J. F., Starr, A. J., CooGAN, P. A., PANDOLFI, S., LAING, I., BECKER, R., AND HAss, G. M. (1974). Electron microscopic and chemical studies of the vascular changes and edema of lead encephalopathy. Amer. J. Pathol. 74, 21 5-240.
Culumbano, A., Ledda, G. M., Sirigu, P., Perra, T., AND PANI, P. (1983). Liver cell proliferation induced by a single dose of lead nitrate. Amer. J. Pathol. 110, 83-88.

Davson, H., AND OldENDORF, W. H. (1967). Transport in the central nervous system. Proc. Roy. Soc. Med. 60, 326-329.

Debault, L. E., AND CANCILlA, P. A. (1980a). $\gamma$-Glutamyl transpeptidase in isolated brain endothelial cells: Induction by glial cells in vitro. Science 207, 653-655.

Debault, L. E., ANd Cancilla, P. A. (1980b). Induction of $\gamma$-glutamyl transpeptidase in isolated cerebral endothelial cells. In The Cerebral Microvasculature (H. M. Eisenberg and R. L. Suddith, Eds.), Vol. 131, pp. 79-88. Plenum, New York.

Debault, L. E., And Cancilla, P. A. (1980c). Some properties of isolated endothelial cells in culture. In The Cerebral Microvasculature (H. M. Eisenberg and R. L. Suddith, Eds.), Vol. 131, pp. 69-78. Plenum, New York.

Delorme, P., Grignon, G., AND GAyet, J. (1968). Ultrastructure des capillaries dans le telencephale du poulet au cours de l'embryogenese et de la croissance postnatale. $Z$. Zellforsch. 87, 592-602.

FRANGAKIS, M. V., AND KIMELBERG, H. K. (1984). Dissociation of neonatal rat brain by dispase for preparation of primary astrocyte cultures. Neurochem. Res. 9, 1689-1698.

Furie, M. B., Cramer, E. B., Naprstek, B. L., AND Silverstein, S. C. (1984). Cultured endothelial cell monolayers that restrict the transendothelial passage of macromolecules and electrical current. $J$. Cell Biol. 98, 1033-1041.

Goldstein, G. W., Asbury, A. K., AND Diamond, I. (1974). Pathogenesis of lead encephalopathy. Arch. Neurol. 31, 382-389.

Goldstein, G. W., Wolinsky, J. S., AND CSEJTEY, J. (1977). Isolated brain capillaries: A model for the study of lead encephalopathy. Ann. Neurol. 1, 235239.

Hial, V., Gimbrone, M. A., JR, Peyton, M. P., WilCOX, G. M., AND PISANO, J. J. (1979). Angiotensin metabolism by cultured human vascular endothelial and smooth muscle cells. Microvasc. Res. 17, 314329.

HiRANO, A., GHATAK, N. R., BECKER, N. H., AND ZIMMERMAN, H. M. (1974). A comparison of the fine structure of small blood vessels in intracranial and retroperitoneal malignant lymphomas. Acta Neuropathol. 27, 93-104.

Holtzman, D., Devries, C., Nguyen, H., Olson, J., AND BENSCH, K. (1984). Maturation of resistance to lead encephalopathy: Cellular and subcellular mechanisms. Neurotoxicology. 5, 97-124.

JANZER, R. C., AND RAFF, M. C. (1987). Astrocytes in- 
duce blood-brain barrier properties in endothelial cells. Nature (London) 325, 253-257.

Lefauconnier, J. M., LAVielle, E., Terrien, N., BerNARD, G., AND FOURNIER, E. (1980). Effect of various lead doses on some cerebral capillary functions in the suckling rat. Toxicol. Appl. Pharmacol. 55, 467-476.

LoMbardi, T., MONTESANo, R., FURIE, M. B., SILVERSTEIN, S. C., AND ORCI, L. (1986). Endothelial diaphragmed fenestrae: In vitro modulation by phorbol myristate acetate. J. Cell Biol. 102, 1965-1970.

LudwIN, S. K., KoseK, J. C., AND ENG, L. F. (1976). The topographical distribution of S-100 and GFA proteins in the adult rat brain: An immunohistochemical study using horseradish peroxidase-labelled antibodies. J. Comp. Neurol. 65, 197-208.

Maxwell, K., Berliner, J., and Pasquale, A. C. (1987). Induction of $\gamma$-GTP in cultured cerebral endothelial cells by a product released by astrocytes. Brain Res. 410, 309-314.

MAXWEll, K., VinTers, H., Berliner, J., Bready, J., AND CANCILlA, P. (1986). Effect of inorganic lead on some functions of the cerebral microvessel endothelium. Toxicol. Appl. Pharmacol. 84, 389-399.

Nguyen, H. T., Olson, J., Devries, C., Savage, W., AND HOLTZMAN, D. (1982). Scanning electron microscopy study of lead effects on cerebral astrocytes in primary culture. Scanning Electron Microsc. II, 891896.

Nye, A. C., Pounds, J. G., Bowman, P. D., and GoldsteIN, G. W. (1985). Cellular lead homeostasis and toxicity in cultured brain capillary endothelial cells. Toxicologist $\mathbf{5}, 135$.

ORLOWSKI, M., SESSA, G., AND GREEN, J. P. (1974). $\gamma$ Glutamyl transpeptidase in brain capillaries: Possible site of a blood-brain barrier for amino acids. Science 184, 66-68.

PENTSCHEW, A., AND GARRO, F. (1966). Lead encephalomyelopathy of the suckling rat and its implications on the porphyrinopathic nervous diseases. Acta Neuropathol. 6, 266-278.

REESE, T. S., AND KARNOVSKY, M. J. (1967). Fine structural localization of blood-brain barrier to exogenous peroxidase. J. Cell Biol. 34, 207-217.

Sessa, G., AND Perez, M. M. (1975). Biochemical changes in rat brain associated with the development of the blood-brain barrier. $J$. Neurochem. 25, 779782.

SILBERGELD, E. K. (1985). Neurotoxicology of lead. In Neurotoxicology (K. Blum and L. Manzo, Eds.), Vol. 3, pp. 299-322. Dekker, New York.

SILBERGELD, E. K., WolinSKY, J. S., AND GoldSTEIN, G. W. (1980). Electron probe microanalysis of isolated brain capillaries poisoned with lead. Brain Res. 189, 369-376.

STEWART, P. A., AND WILEY, M. J. (1981). Developing nervous tissue induces formation of blood-brain barrier characteristics in invading endothelial cells: A study using quail-chick transplatation chimeras. $D e$ velop. Biol. 84, 183-192.

Thomas, J. A., Dallenbach, F. D., AND Thomas, $M$. (1973). The distribution of radioactive lead $\left({ }^{210} \mathrm{~Pb}\right)$ in the cerebellum of developing rats. J. Pathol. 109, 4550.

TIFfANY-CASTIGlioni, E., ZMUDZKI, J., WU, J., AND BRATTON, G. (1987). Effects of lead treatment on intracellular iron and copper concentrations in cultured astroglia. Metab. Brain Dis. 2, 61-79.

Toews, A. D., Kolber, A., HaYWard, J., KRIGMAN, M. R., AND MORELL, P. (1978). Experimental lead encephalopathy in the suckling rat: Concentration of lead in cellular fractions enriched in brain capillaries. Brain Res. 147, 131-138.

VOYTA, J. C., VIA, D. P., BUTTERFIELD, C. E., AND ZETTER, B. R. (1984). Identification and isolation of endothelial cells based on their increased uptake of acetylated-low density lipoprotein. J. Cell Biol. 99, 2034.

WOLFF, J. (1963). Beitrage zur Ultrastruktur der capillaren der normalen grosskirnrinde. Z. Zellforsch. 60, 409-431. 